\title{
FAMILY CONFLICT IN E. LOCKHART'S NOVEL WE WERE LIARS
}

\author{
Tri Mauli Dina, Andang Suhendi \\ English Department, Faculty of Literature, \\ Universitas Islam Sumatra Utara, Medan, Indonesia \\ e-mail: trimaulidina05@gmail.com
}

\begin{abstract}
This paper discusses the causes of the conflict in the family in E. Lockhart's novel We Were Liars. There are there causes of the conflict in the family occurred in the novel. They are different social system, different personality, and needs. The method used in analyzing the topic in this paper is qualitative research method. The theory of the types of the causes of conflict used in this analysis is following Wirawan. The first cause is the different social system. This cause deals with different ethnicity and status which are found in the novel. The second is different personality. This cause is triggered by greed, selfishness, and anger. Some characters in the novel show such personalities. Then, the third is needs. The needs of treasure and inheritance result in conflict in the family in the novel. Thus, it can be found that the family conflicts in the novel are due to three main causes; they are the different social system, the different personality, and the needs.
\end{abstract}

Keywords: conflict, causes of conflict, social system, personality, needs

\section{Introduction}

Conflicts in a family can occur because of opposition behavior or disagreement between family members. Family conflict is more often compared to conflict in other social contexts. This could be due to the amount of time spent together more than outside. The frequency of conflict reflects the quality of the relationship, meaning that the quality of the frequency of conflict is less. Relationship quality can influence the individual's way of framing conflict issues.

Conflict is an aspect that always exists in life, both real life and life in the world fiction. Conflict is also important points in the plot of a story. Without a conflict, the story will not be interesting to be enjoyed. There must be conflicts in our lives. No one has never experienced with conflict. Conflict can happen between its members or with other community groups. Conflict will only disappear along with the disappearance of the community itself. This is in accordance with the statement that conflict is important to literature because it provides the basic materials for the construction of the story (Aiyede, 2006). It means that without conflict, nothing would happen.

Conflict is a social symptom araises in social life. Conflict will always exist in every space and time, anywhere and anytime. From each conflict, there are some of them that can be resolved, but there are also some that cannot be resolved resulting in several acts of violence. Conflict means disputes. Conflict is the process of achieving goals by weakening the opposing party, without regard to prevailing norms and value. 
In another sense, conflict is a social process that takes place by involving people or groups that challenge each other with the threat of violence.

In general, conflict is a serious disagreement about opinions, views, passions or expectations. That is normal for humans to have problems in their lives. This problem may be a conflict if there is no way out to get solution. The main reason for conflict arises between or among people is the disagreement about many things. Conflicts can occur for everyone, everywhere, everytime, no matter whether or not they are rich or poor.

From the various meanings above, it can be concluded that conflict is a quarrel or disputes that occur between members or the community in order to achieve something desired by challenging each other with the threat of violence.

Conflict will stimulate people to think critically about the position of the opponent of the conflict and position themselves. People must understand why the opponents of the conflict have different opinions and maintain their opinions. His creativity is increased which is used in compiling strategies and tactics to deal with the conflict.

To make the analysis more scientific, the writers use descriptive qualitative method proposed by (Blaxter, L., Hughes, C. and Tight M.2001). According to them, qualitative descriptive method concerns analysis of information in many forms including text. Thus, the qualitative method is proper method to be used, explain, or narrate data in words or paragraphs, and it is also supported by Setiawan, Barus, and Pawiro (2017) who claim that this is an appropriate method conducted as it gives detailed points of some social events.

\section{Literature Review}

O. Krejčí (2007) defines a conflict as a situation, in which a certain group (tribe, ethnic group, ideological group or state) or an individual is in a purposeful dispute with one or more groups or individuals. A conflict is a struggle for values relating to the maintenance or increase of welfare, status or power. According to Š. Waisová (2002) a conflict is a social reality, in which at least two parties (individuals, groups, states), with a different outlook on certain facts or different, contradictory interests, stand in opposition. According to her, a conflict represents a situation in which, at the same time, a minimum of two parties are striving to obtain the same goods, which are deficient and cannot satisfy the needs of both (all) parties (Waisová, 2005).

D. Kusá defines a conflict as a state in which one or two (or more) people and communities feel that their interests are incompatible. They usually have an antagonistic approach towards each other, which they show by trying to cause the other party harm. They seek to assert their own interests by influencing the other party (Kusá, 2006). F. Glasl provides a more specific definition of a conflict, as an interaction between agents (individuals, groups or organizations), where at least one agent understands that their thoughts, ideas, perceptions and/or feelings are incompatible with the will, thoughts, feelings, etc. Of another agent (or agents) and s/he feels limited by their activities (Mischnick, 2007). A conflict represents a certain quality of relations between units of a social environment (parties involved, which may be individuals, social groups, states or a coalition of states), which are manifested in the efforts of certain parties involved to promote their own needs, achieve their own interests and objectives at the expense of and against the wishes of their opponents, or which are contradictory to the interests of their opponents (Hofreiter, 2008). 
Conflict is different perceptions, which may not necessarily result in hostility. This way, conflict simply means 'a different perception' or view to an issue or situation (Barash and Webel, 2002). Here, it may mean a different interpretation of a motive, or a different world-view. These include religion, customs, cosmologies or values. Such differences may never culminate in direct and sharp confrontations. On the other hand however, different perceptions, values or world-views may transcend just 'differences' and result in the extreme connotation of conflict.

Conflict is a struggle or contest between people with opposing needs, ideas, beliefs, values, or goals. Defined in broadest terms, conflict denotes the incompatibility of subject positions (Diez et al, 2006: 565). This definition emphasises the opposition or incompatibility at the heart of the conflict, and initially leaves open the exact nature of these incompatibilities, i.e. whether they are between individuals, groups or societal positions; whether they rest in different interests or beliefs; or whether they have a material existence or come into being only through discourse. Given this initial definition, conflict is not always characterised by violence. Yet, conflict might escalate and lead to destructive results, in particular in the form of physical violence that is increasingly seen as legitimate as conflict intensifies.

Wirawan (2009: 106) says that conflict has a major influence on the lives of humans, both individually and in groups. Conflict has a positive and negative influence. Both of these influences create changes in human life. Conflict changes and develops human life for the better.

\subsection{Causes of Conflict}

\subsubsection{Limitedness Sources}

Humans always experience limitedness of sources needed to support their life. The limitedness causes competitions among humans to get the sources needed, and in this case, it frequently causes conflicts.

\subsubsection{Different Goals}

As stated by Hocker and Wilmot (1978), a conflict occurs because the parties involved in the conflict have different goals. A conflict can also occur because the involved parties have the same goals, but the ways to achieve are different.

\subsubsection{Different Social System}

In Indonesia, conflicts in society frequently occur because its members have diverse characteristics: tribes, religions, and ideologies. The characteristics are frequently followed by exclusive way of living between one and another that frequently causes conflicts.

\subsubsection{Different Personality}

Some people have personality that easily causes conflicts, such as being suspicious and having negative thinking towards other people, selfish, arrogant, always thinking that he/she is right, not able to control his/her emotions, and always wanting to win. The characteristics easily trigger conflicts in interaction with other people. 


\subsubsection{Needs}

People have different needs from each other or have the same needs for something with limited amount. Needs are the support of human behavior. If the needs are neglected or obstructed, it can trigger conflicts.

\subsubsection{Feelings and Emotions}

People also have different feelings and emotions. Some people follow their feelings and emotions when they interact with something or other people. People who are highly affected by their feelings and emotions become irrational when they interact with other people. The feelings and emotions can cause conflicts and determine their behavior when they get involved in a conflict.

\subsubsection{Violence Culture}

Since the independence of Indonesia until entering the 21 st century, Indonesia always experiences political, economic, and social conflicts continuously. The change of mindset from togetherness mindset into individualistic mindset, primordialism, waning sense of nationalism, political life and liberal economy, disappearance of traditional values, and religious politicization have contributed to develop conflict culture in Indonesia.

\section{Research Method}

According to John W. Cresswell (2009: 3), research design are plans and the procedures foe research that span decisions from broad assumptions to detail methods of data collection and analysis. This research is in the form of qualitative research method with narrative approach. Qualitative research is a means for exploring and understanding the meaning of individuals or groups that describe to a social or human problem. The process of research involves emerging questions and procedures: collecting data in the participant's setting; analyzing the data inductively, building from particulars to general themes and making interpretations of the meaning of the data. The final written report has a flexibel writing structure.

\section{Discussion}

\subsection{The Causes of the Family Conflict 4.1.1 Different Social System}

Conflict can occur because each individual or group has different ethnicity, culture and ideology. These differences tend to make someone who just want to hang out based on certain group of ethnicity, religious, ideological. This characteristic is often accompanied by a pattern of life that is exclusive to one another. So, most individuals who feel themselves special. For example, in terms of material, they will look for people who are worth because they are considered more suitable. This also happens in the novel We Were Liars, where Haris Sinclair has his own criteria in determining who is entitled to become a member of his family. Not only individuals will show themselves off exclusive but also they will regard themselves different from others; ethnicity, personal, status difference that are analysed in detail below.

\subsubsection{Ethnicity}

In the novel We Were Liars the Sinclair family is a native American family, so all members of the Sinclair family have American characteristics: tall bodies, red hair, 
sharp nose, pointed chin and white skin. Physically, they are amazing, their beauty and good looks are undoubted and they have been recognized by people around them. Haris Sinclair, the protagonist, and as head of the family is very proud of that. His three daughters and all his grandchildren became true Sinclair. Because of this condition, Haris does not like it if there are foreigners who come from foreign tribes to become the Sinclair's family.

"He calls me young man. Like, How was your school year, young man?" "Why?" "It's like, if he called me Gat he'd be really saying, How was your school year, Indian boy whose Indian uncle lives in sin with my pure white daughter? (E. Lockhart, 2014: 48)

The above quotation describes that Haris does not like Gat and Ed, his uncle, because they are from India. They have a physical characteristic of India: dark brown skin and black hair. Haris does not like them, even though they have known each other for a long time. Gat is a friend of his grandchildren. They always spend vacation time together on the private island of the Sinclair family while Ed is the lover of Carrie, his daughter. Even though he allows his grandson to interact with Gat. He even becomes a close friend, but he still will never consider Gat and for him Gat is still a stranger and not suitable to be part of the Sinclair's family. He never calls Gath or mentions the name of Gat even though he knows it, this was a form of his dislike of Gath. He always calls Gat by saying the word young man.

"But back when Carrie first moved in with Ed, Harris made it clear that all the money earmarked for her would disappear if she married him. “The point is, Harris doesn't like Ed's color. (E. Lockhart, 2014: 48)

The above quotation shows that Haris will not even hesitate to use his threat to the princess. He threatens Carrie that he will remove Carrie's name from the list of her inheritance if Carrie marries Ed. Carrie does not dare to deny what is said by her father. She does not want to lose her inheritance. Without money or inheritance from his father, he is not sure he can live comfortably without it. Even so, he remains in a relationship with Ed, they live together and had a child. Haris does not mind that. The most important thing for him is that he does not want Ed to become a member of the Sinclair's family officially. He knows that this is his daughter's way of melting his heart, because his daughter knows that he is very famous for his granddaughter and tended to grant his grandchildren's wishes. But this can change his decision, even though he allows it and considers their children their grandchildren. He still will not let his daughter marry Ed, who comes from an Indian tribe as seen in the following quotation.

"We could see she was a Sinclair. She had that hair, but it wasn't only that. It was the chin, the tiny hands. We knew she'd be tall. All of us were tall until Bess married that short fellow, and Carrie made the same mistake." (E. Lockhart, 2014: 20)

In addition, Haris also thinks that marriage done with someone who has differences with us is a mistake. That is why there are no harmonious households of the three daughters and end in divorce between them. No one has a whole family, their husband left them, because they cannot continue with the Sinclair's family. They realizes that they are different from their wives' families so even though they have tried 
their best to be accepted into the Sinclair's family they still fail. There is always rejection and shown by the father of their wife to them indirectly. This is what triggers them to separate from the Sinclair family's daughter and look for a new life with other women who can accept them differently.

\subsubsection{Different Status}

Apart from being famous for the beauty and beauty that the Sinclair's family possesses, they are also famous for the wealth they have. They belong to a respected family in America. Everyone admires their family. They live very well or even more than enough. Haris Sinclair owns a private island and he gives each of his luxury homes to his children on the island. Haris's social status is very high based on the amount of wealth he has, so he does not like Ed's daughter's lover who is from the middle class.

"This Ed, he was an art dealer"

"Did you know my uncle proposed to Carrie, back in the fall?" Gat asked. I shook my head. "They've been together almost nine years.He acts as a dad to Johnny and Will. He got down on his knees and proposed... but Carrie said no.”(E. Lockhart, 2014: 48)

Carrie refuses Ed's proposal, because her father does not like Ed who is only an art seller. Even though they have lived together for nine years and already have two sons. This does not make Carrie accept Ed to be her husband. According to her, they just live their lives as usual without marriage ties, but Ed thinks differently. According to Ed, the marriage is important for their next life and he can formally be father to the two sons. Carrie cannot accept Ed to be her husband even though she wants it too. She knows Ed is very responsible for Will, their biological son, but also she loves Carrie's son Johny from her ex-husband. Carrie can do nothing but follow her father's orders which does not allow her to marry Ed. He cannot deny his father's wishes because he still lives dependent on his father until now.

\subsubsection{Different Personality}

The personality possessed by each individual must be different. Some have good personalities and some do not. This bad personality often triggers conflicts such as suspicious, greedy, negative thinking, selfish, arrogant, and so forth.

\subsubsection{Greed}

Greediness is the nature of a person where he feels not enough for what he has. $\mathrm{He}$ still wants more, more, and more. Even though he already have it, he still feels lacking.

Bess had already inventoried Gran's Boston possessions and now began with those in Clairmont. The aunts had copies on their tablets and pulled them up regularly. "I always loved that jade tree ornament." "I'm surprised you remember it. You never helped decorate." "Who do you think took the tree down? Every year I wrapped all the ornaments in tissue paper." "Martyr." "Here are the pearl earrings Mother promised me." "The black pearls? She said I could have them." The aunts began to blur into one another as the days of the summer ticked past. Argument after argument, old injuries were rehashed and threaded through new 
ones. Variations. "Tell Granddad how much you love the embroidered tablecloths," Mummy told me. (E. Lockharts, 2014: 46)

The above quotation indicates that Bess had moved her mother's inheritance to her house as well as her siblings, Carrie and Penny. They have taken their mother's inheritance and brought it to their homes. They also have copies of what items they can take from their mother's house. Even so, they kept fighting, there were just things they fought over that triggered a fight, and no one wanted to budge among them. There is always a commotion between them. They never feel enough and are satisfied with what they have. Even though they have taken a lot of valuables from their parents' house and are sufficient to meet their needs, there is still something to be contested. Even to fulfill their dissatisfaction with what they had, Cadence's mother who wanted the tablecloth that was in the house and didn't want it to be taken by her two siblings asked her daughter to tell her grandfather directly that she liked the tablecloth which was most likely her grandfather would immediately give it to her daughter. Items like that are also contested by them.

\subsubsection{Selfishness}

Selfishness or wanting to win alone is one of the traits that are often the trigger for conflict between individuals, where he feels more entitled and does not want others to get what he gets. It can be verified in the quotation below.

"Don't tell me what I mean!" shouted Bess. "You have Ed. You don't need money like I do... "Who did the funeral arrangements for Mother?" snapped Bess. "Who stayed by Dad's side for weeks, who went through the papers, talked to the mourners, wrote the thank-you notes?"..."Either of you could have come for a week or two. You left it all to me," said Bess. "I'm the one who has to deal with Dad all year. I'm the one who runs over when he wants help. I'm the one who deals with his dementia and his grief." (E. Lockhart, 2014: 49)

Bess feels that she is more entitled to get the island than her sisters, because all this time she is the one who always helps her parents. She who always accompanies and cares for her father. She takes her mother to the hospital and waits for her. She always does whatever is needed by her parents while the two sisters did nothing for their parents. They are too busy with their own affairs so they ignore the existence of their parents. They always have many reasons when needed as a home away, taking care of children, being busy, and so on. But when the distribution of assets actually they ask for more parts, Bess felt she is more deserving of it than her two sisters who does nothing for their parents. They do not have the right to it all; that is his right. She is more deserving of the island.

\subsubsection{Anger}

A person's anger towards others can also cause conflict. When someone is angry, she tends to do or says not irrational and prioritize venturing that anger to anyone as seen in the following quotation.

"Why didn't you back me with your grandfather? Do you want us to lose this house?" "We don't need it." "I picked the paint, the tiles. I hung the flag from the porch." "It's five bedrooms." "We thought we'd have a 
bigger family." Mummy's face got tight... Mummy stood up. "You're filled with superiority, aren't you? You think you understand the world so much better than I do. (E. Lockhart, 2014: 47)

The above quotation shows that Penny, Cadence's mother, scolds her because she does not support her mother when there is a debate at her grandfather's house when her mother and her two aunts fight over a house. Even if Cadence supports her mother just a little, namely by telling her grandfather that she wants the house, her grandfather will immediately give him the house so that her mother does not need to fight with her aunts. Penny does not do that because she thinks that indeed Bess, the mother of Mirren, needs the house more because she has many children so that it suits the larger and wider house. She tries to give an explanation of it and tells them that their lives are more than adequate than the lives of others outside. Her mother immediately stands up when she hears the explanation. She does not accept the explanation given by her. She scolds Cadence for not obeying and she tells Cadence that she does not know anything about life. She does not know what they need and how to pay it because she has always known nothing about it. She still lives depending on her mother.

Not only Penny but also Cadence's mother who has a temper, her aunts also have angry temper. They will immediately get angry if there is someone who is not according to their wishes. It is seen in the quotation below.

It was the aunts coming into the kitchen, their speech slurred and hysterical. "This is why people kill each other," said Bess bitterly. "I should walk out of this room before I do something I regret." "You don't mean that," said Carrie. "Don't tell me what I mean!" shouted Bess. "You have Ed. You don't need money like I do."... "Shut up about Ed!" cried Carrie. "Just shut up, shut up." There was a slap-Carrie hit Bess across the mouth. Bess left. Slamming doors. Mummy left, too. (E. Lockhart, 2014: 49)

The quotation above describes that Penny, Carrie and Bess are shouting each other for one of their father's islands. Nobody succumbs to them. They keep shouting hysterically when they argue. Bess is even convinced that they may just kill each other just to fight over this. They do not care that they are sisters. That could happen in the middle of their quarrels which have been overpowered by emotions so they cannot control their actions. Even Carrie slapped Bess, only because Bess comments on her life living with Ed to have a child without marriage ties. Carrie is very angry at Bess's words so she slapped him.

\subsubsection{Needs}

People have needs that are different from each other or have the same needs as to something that are limited in number. Needs are the drivers of the occurrence of human behavior. If the needs of neglected or hampered, then could trigger the onset of the conflict.

\subsubsection{Treasure}

Treasure must be very stunning especially for women. Every woman will want to have it like silver and crystal objects. It is seen in the following quotation. 
For the old people in my family-Mummy, the aunties, Granddad - the accumulation of beautiful objects is a life goal. Whoever dies with the most stuff wins. (E. Lockharts, 2014: 18)

The above quotation shows that the life goal of the women in the Sinclair family is to collect as many treasure as possible, such as silver, crystals, books as decorations, blankets, carpets, paintings and even spoons. They do this like a race. Who can collect it better then she is the winner. They do not care how life actually goes in the future, for them the most important thing is that they can buy all the things and defeat their sisters. They even quarreled over the statues and paintings in their mother's house. In fact, it is of no use in their lives, other than for their satisfaction while those who do not want to be judged by others and their siblings.

House and money are the things most needed by humans for their survival. So, it is not surprising that many people fight over this and get involved in conflict. House and money is one of the causes of the conflict that occurred in the Sinclair family. They have a fairly decent survival compared to others, but they keep fighting over it all. They need it all not for their survival, but because they are greedy and want to have everything. They want to have everything their parents have.

We watched them quarrel over Gran's things and the art that hung in Clairmont - but real estate and money most of all. Granddad was drunk on his own power and my mother wanted me to make a play for the money. Because I was the oldest boy. She pushed me and pushed me-I don't know. (E. Lockhart, 2014: 45)

The above quotation indicates that after fighting over all the items in their parents' homes, the daughters of Harris Sinclair fought over the house and money that their parents also have. They always want the same thing that their parents have. That is what continues to cause fights between them. Even though they do not really need it, they insist on getting it and they feel it was their right. All of them feel that it is their right, so no one wants to succumb to them. Even they do not hesitate to use their children so they can get what they want. They force their children to persuade their father so that they will get what they want. They also have no problem if they have to speak ill of each other for it all. It is seen in the quotation below.

"This is my house. You can't expect me to give it up because Bess had too many children and left her husband. You can't think it's okay for her to snatch it from me. This is our place, Cadence. We've got to look out for ourselves." "Can you hear yourself?" I snapped. "You have a trust fund!" "What does that have to do with it?" "Some people have nothing. We have everything. The only person who used the family money for charity was Gran. Now she's gone and all anyone's worried about is her pearls and her ornaments and her real estate. Nobody is trying to use their money for good (E. Lockhart, 2014: 47)

The quotation above shows that they do not think of anything other than house and money, even if they forget your bond that is interwoven. They behave as if they were strangers and they are not obliged to pity or help her. None of them thought how to use the money for other useful things other than fighting over it and ended in a fight. They are not grateful for what they already have compared to other people who are 
more in need between them. Even after the death of their mother, this conflict continues and still fights for something in common. They do not follow the way their mother use their money for charity and help those who are more in need.

\subsubsection{Inheritance}

It has become a common thing if the inheritance of a parent can certainly cause conflict to his heir. There must be an heir who disagrees with the provisions of the inheritor, she does not accept the division decided by the heir. It can be reflected in the following quotation.

"I'll relax when the estate is settled." "You're making us crazy," Carrie muttered. "What was that? Don't mumble." "We all love you, Dad," said Carrie, loudly. "I know it's been hard this year." "If you're going crazy it's your own damn choice," said Granddad. "Pull yourself together. I can't leave the estate to crazy people." (E. Lockhart, 2014: 32)

The above quotation describes that Penny disagrees with the wishes of her father who wants Bess to help him redecorate the house in Boston, one of the houses they want. This can be used as an excuse by Bess that she is more entitled to the house because she is redecorating. Penny knew thats Bess had never been sincere in helping their father there must have been a request from him in return, despite the fact that Bess was more often helping their father than he was. Penny thinks Bess will definitely not waste this opportunity in order to master the inheritance of their father. Not only did Penny disagree with Harris Sinclair's father's wishes, Carrie also refused. Carrie did not approve it because she knew this could threaten her position in obtaining inheritance from her father. She could get less inheritance than Bess or even he would not get an inheritance. If until that happened Carrie could not imagine it or even she could go crazy.

From the analysis of conflict in the family in E. Lockhart's novel We Were Liars, there are a number of points found. The conflicts in family in the novel We Were Liars were the conflicts between Harris Sinclair and his daughters, Harris and his daughters' husbands, his three daughters and their children, and Harris and the persons who befriended his grandchildren. Another cause of conflicts in Harris Sinclair's family was the difference of ethnicity between Carrie, Harris' daughter, who was original descendant, while her future husband, Ed, was an Indian descendant. The difference of status between Carrie, who was a nobleman's daughter and Ed, who was only a simple art seller. Neither Harris liked Gat, Ed's nephew, who established a relationship with his grandchild. The relationship among Harris' Sinclair three daughters were really bad. They always got into a fight when they met because they wanted to control all of their parents' property. Besides that, they did not hesitate to kill to get inheritance from their father without paying attention to the sisterhood among them. The conflicts in Harris Sinclair's family were not only among Harris Sinclair's daughters, but also among his grandchildren. They felt depressed by the worsening situation at home, the fight among their parents, the pressure from their parents to obey their wills, the demand to compete with their own cousins, and no words of objection accepted by their parents. 


\section{Conclusion}

After conflict in the family in E. Lockhart's novel We Were Liars has been analyzed, some conclusions can be drawn up. The causes of conflicts in family in the novel could be classified into three types, namely different social system, different personality, and needs. The different social system that occurred is such as different ethnicity and status in the society. Personality that frequently caused conflicts are someone's bad personality such as greed, selfishness, and anger. Harris Sinclair had three daughters, Penny, Bess, and Carrie. Finally, needs also become the cause of conflicts.

\section{References}

Aiyede, Emmanuel R. (2006). Theories in Conflict Management. Nigeria: National Open University of Nigeria.

Ashton, M. C., \& Lee, K. (2001). A theoretical basis for the major dimensions of personality. European Journal of Personality, 15, 327-353. http://dx.doi.org/10.1002/per.417. Accessed September 2019.

Berkowitz, Leonard. (1993). Aggression: Its Causes, Consequences and Contract. Philadelphia: Temple University Press.

Blaxter, L., Hughes, C. and Tight M. (2001). How To Research. USA: Open University Press.

Barash, D.P. and Webel, C.P. (2002). Peace and Conflict Studies. Thousand Oaks, CA: Sage Publications.

Diez, Thomas, Stetter, Stephan. \& Albert, Mathias. (2006). The European Union and Border Conflicts: The Transformative Power of Integration. International Organization. Vol. 60, no. 3.

D'Souza, J. (2015). Greed: Crises, Causes, and Solutions. International Journal of Humanities and Social Science. Vol.5, no 7.

Gross-Stein, Janice. (1996). 'Image, Identity and Conflict Resolution' in Chester A. Crocker and Fen Olser Hamson, (eds) Managing Global Chaos: Sources and Responses to International Conflict. Washington: United States Institute of Peace Press.

Gurr, Robert. (2000). Peoples Versus States: Minorities at Risk in the New Century. Washington: United States Institute of Peace Press.

Herbert, Martin. (1990). Planning A Research Project: A Guide for Practitioners and Trainer in Helping Profession. London: Cassel Education Limited.

Hofreiter, L. (2008). Teória a riešenie konfliktov. Liptovský Mikuláš: Akadémia ozbrojených síl generála M. R. Štefánika Liptovský Mikuláš.

Indati, Aisah. (1996). Konflik pada Anak: Pengaruh Lingkungan dan Tahap Perkembangan. https://psikologi.ugm.ac.id/aisah-indati-2/. Accessed April 2019.

Indayani. (2006). The Main Charcter's Conflict in Maxwell nderson's Play "Winterset". http://repo.iain-tulungagung,ac.id. Accessed August 2019.

Krejčí, O. (2007). Mezinárodní politika. Praha: EKOPRESS.

Kusá, D. (2005). Riešenie konfliktov. Bratislava: Mirius.

Lindner, Evelin G. (2006). Making Enemies: Humi-liation and International Conflict. London: Praeger. 
Mischnick, R. 2007. Nenásilná transformácia konfliktov. Manuál pre tréning trénerov. Bratislava: Don Bosco.

Rastislav, Kazanský. (2015). The Theory of Conflicts. Banská Bystrica: Matej Bel University.

Setiawan, Muarif, Barus, Efendi, and Pawiro, Mhd. Ali. (2017). Cause and effect of suffering in Sydney Sheldon's "If Tomorrow Comes". Language Literacy: Journal of Linguistics, Literature, and Language Teaching. Volume 1, Number 1, Desember 2017, Pages: 73-96 https://jurnal.uisu.ac.id/index.php/languageliteracy/article/view/247/236 Accessed September 2019.

Smith, Anthony D. (1986). The Ethnic Origins of Nations. Oxford: Blackwell.

Waisová, Š. (2002). Úvod do studia mezinárodních vztahů. Plzeň: A leš Čenek.

Waisová, Š. (2005). Řešení konflikti̊ v mezinárodních vztazích. Praha: Portál.

Wirawan. (2009). Evaluasi Kinerja Sumber Daya Manusia. Jakarta: Salemba Humanika.

Wirawan. (2010). Konflik dan Manajemen Konflik: Teori. Aplikasi, dan Penelitian. Jakarta: Salemba Humanika. 